\title{
Application of Problem Based Learning (PBL) in a Course on Financial Accounting Principles
}

\section{NOR AZIAH ABDUL MANAF ${ }^{1}$ \\ ZUAINI ISHAK ${ }^{2}$ \\ WAN NORDIN WAN HUSSIN ${ }^{3}$}

College of Business

Universiti Utara Malaysia

aziah960@uum.edu.my ${ }^{l}$;

zuaini@uum.edu.my';

wannordin@uum.edu.my ${ }^{3}$

\section{ABSTRACT}

Purpose - This paper aims to share experiences in teaching a Financial Accounting Principles course using a hybrid problem based learning (PBL) method. The three specific objectives of this paper are to document how the PBL project for this course was developed and managed in class, to compare the academic performance of PBL students with non-PBL students, and to investigate the students' perceptions of how PBL had benefitted them. peceptions of how PBL had benefitted them.

Method - Based on our experience of the processes in developing and managing the PBL project, we described that process in this paper. Then, from the overall results of 1,148 students taking the Financial Accounting Principles course, we compared the academic performance between PBL and non-PBL students. In addition, we used a questionnaire to find out from the 267 students who had attended the PBL and the traditional non-PBL methods, how the various activities in the Financial Accounting Principles class had benefited them.

Findings - The results showed evidence of the superiority of the PBL method. The PBL students out-performed those without the benefit of a PBL experience. The survey results also indicated that a PBL approach provided significant benefits to the students in their presentation skills, teamwork, leadership and ability to use IT. In addition, student responses to the open-ended questions revealed that PBL was an acceptable way of learning accounting. PBL was 
a challenging way of learning, but it offered great benefits; PBL helped our students in the experimental group to improve teamwork, communication and other soft skills. However, we found PBL to be suitable only for students with some basic accounting knowledge.

Significance - PBL is an innovative teaching method because it uses problems in stimulating students to learn. This study has shown that PBL is a promising approach in teaching accounting. The major challenge for educators using this approach is to be able to provide well-developed problems in order to achieve the desired learning outcomes of the course.

Keywords: PBL, PBL in accounting, teaching accounting, learning through PBL.

\section{INTRODUCTION}

Problem-based learning (PBL) has been implemented widely in many schools and universities all over the world. PBL places partial and explicit responsibility on the students for their own learning. Unlike the conventional stand-and-deliver lecturer-centered approach where students listen passively to lectures, PBL emphasizes active, - interactive and collaborative learning, making it more student- centered (Azer, 2009; Hansen, 2006; Clouston \& Whitcombe, 2005; Duch, Groh and Allen, 2001; Siaw, 2000; Vernon \& Blake, 1993). Thus in PBL, the teacher acts to facilitate the learning process rather than to provide knowledge.

The PBL project is an instructional approach that involves confronting students with problems from practice, and these problems provide the stimulus for learning. PBL makes use of problems to help one focus on learning. It prepares students to think critically and analytically, and helps them develop problem-solving skills whilst searching for and gaining the appropriate knowledge.

In a report issued in 1990, the Accounting Education Change Commission in the U.S.A. emphasized that "the overriding objective of accounting programs should be to teach students to learn on their own" (AECC, 1990, p. 309). The Hala Tuju 2 (Reassessment Report) on Accounting Programs at Public Universities in Malaysia (2006) pointed out that problem-based learning and student-centered learning should be part of the pedagogical repertoire in institutions of higher learning. Flanagan (1997) underscored the importance of 
using PBL in introductory accounting courses, regarding PBL as a means of addressing the criticisms from professional accounting bodies on the perceived inadequacies among accounting graduates in communication skills, information technology competence, problem solving skills and the ability to work effectively in groups.

There have been numerous studies which showed that PBL is a superior approach to the traditional-lecture type approach in improving students' learning skills in problem solving (Newble \& Clark, 1986), overall grade (Lai et al., 1999; Breton, 1999) and the students' attitudes and opinions about their program (Vernon \& Blake, 1993). Vernon and Blake's findings showed that PBL students not only placed more emphasis on understanding compared to students from traditional programs, but also demonstrated a greater independence in their learning method than did the traditionallecture type students. Siaw (2000) highlighted that most students felt group interaction not only enhanced their learning, enabled them to support each other in their own group, and made sharing easier, but also made it the most valuable part of learning in the PBL experience. Her study on using PBL in the teaching of accounting and statistics was yet another empirical support of the more general belief that PBL as a pedagogical approach was perceived to be more successful in the Accounting discipline.

However, research had also shown that PBL has not always been effective (O'Neill, 2000; van Gessel, Nendaz, Vermeulen, Junod, \& Vu, 2003). Farnsworth (1994) was of the view that PBL was an ineffective instructional method because learners had to gather information through self-directed learning, and it was costly because it required more faculty and time to conduct the course. Kirschner et al. (2006) also claimed that PBL was less effective than traditional methods because its approach of providing minimum guidance was not compatible with our human cognitive architecture.

Comparing students' performance on progress tests under PBL and traditional curriculum, Verhoeven et al. (1998) found that the traditional students obtained better scores on basic science while PBL students performed better on social science. In addition, to their surprise, the PBL students did not outperform non-PBL students in clinical science in the first and second years of their program.

According to Hung (2009), the design of problems is crucial for PBL to be effective. Hung developed the 3C3R PBL problem design model as a conceptual framework for guiding the design of reliable and effective PBL problems for all levels of learners by addressing the specific characteristics of PBL and its implementation. 
The 3Cs represent content, context and connection, while the 3Rs comprise researching, reasoning, and reflecting, which support the cognitive processes of problem solving skills and self-directed learning. For accounting courses, Hansen (2006) suggested that it was possible to make end-of-chapter problems in accounting into a PBL project to reflect real world problems. This would help students to think critically, develop skills to find learning resources, work cooperatively and communicate effectively.

As part of the innovative teaching and learning initiative at Universiti Utara Malaysia (UUM), we have since the First Semester 2006/07, embarked on the PBL method at the Faculty of Accountancy (presently known as the UUM College of Business or UUM COB). We embedded (partially) this PBL project in the Financial Accounting Principles course. Accounting, Finance and Banking students in their first year of undergraduate studies had to take this course. For that semester, we conducted the PBL and nonPBL classes concurrently. The problems highlighted in the project were specific problems faced by a fast-growing company involved in the halal food manufacturing business. These authentic problems either had to do with the manual recording of transactions, or the use of a computerized system, and the making of sound business decisions.

As PBL as an instructional approach is still at an infant stage in Accounting programs in Malaysia, it is worthwhile to explore the PBL experience in teaching and learning. Thus, the purpose of this paper is to share our experiences in developing and managing the PBL project. We also compared the academic performance of PBL students with that of non-PBL students by analysing their final examination results. Lastly, we investigated how the students perceived PBL in their learning process.

The paper proceeds as follows. The next section highlights the development of the PBL project. Next, we share our experiences in managing the PBL class and provide evidence on the superiority of the PBL method. Then, we present quantitative and qualitative evidence on the benefits of the PBL versus non-PBL method from the students' perspectives. The last section discusses our conclusions.

\section{DEVELOPING THE PBL PROJECT}

In line with the objectives and learning outcomes of the Financial Accounting Principles course, the PBL Project is aimed at achieving the following learning outcomes whereby students will be able to: 
- Identify, classify, record, summarize and report socioeconomic events which affect organizations.

- $\quad$ Prepare financial statements in accordance with approved accounting standards.

- Interpret and evaluate financial and non-financial information for decision-making.

- Use and evaluate information technologies and systems for the attainment of organizational objectives.

Think critically in the application of knowledge, and suggest possible solutions to accounting issues.

Integrate other business and management applications to their basic accounting core competencies.

Work collaboratively in a management team.

Communicate effectively, both orally and in writing, with different stakeholders.

- Demonstrate behaviour consistent with professional ethics and social responsibility.

Demonstrate a commitment to life-long learning and professional development.

Demonstrate leadership and entrepreneurial skills.

We re-constructed a set of problems faced by a fast-growing company involved in a halal food manufacturing business, focusing particularly on the recording of transactions and using accounting information for business decision making, to engage students' curiosity and initiate learning of the subject matter. To ensure that our problems were authentic, so as to reflect a halal food manufacturing business in the real world, we interviewed the CEO of a halal food manufacturing and distributing enterprise, and visited the plant. The problems we posed helped to facilitate the self-directed learning of six of the ten topics found in the syllabus. We divided the problems into four entry documents using memos, and these were integrated into the course content as shown in Table 1.

In organizing the PBL class, we followed the same syllabus as was used in the non-PBL class. However, to achieve the learning outcomes of the course, we created several problems in the entry documents in memo form. The coverage of the topics, the number of weeks allocated, and the learning outcomes for each of the entry documents are as shown in Table 2. 
Table 1

Course Content and Class Activity

\section{NO TOPIC/ACTIVITY}

1. INTRODUCTION TO ACCOUNTING

1.1 What is Accounting

1.2 Accounting Profession

1.3 Internal and External Users of Accounting Information

1.4 Generally Accepted Accounting Principles (GAAP)

1.5 Professional Accounting Bodies and Standard Setting in Malaysia

1.6 Statutory and Capital Market Requirements

1.7 International Accounting Standards Board (IASB)

1.8 Financial Statements

\section{ACTIVITY: LECTURE \& DISCUSSION}

2. THE RECORDING PROCESS

2.1 Business Transaction \& Accounting Equation

2.2 Account

2.3 Chart of Account

2.4 Steps in the Recording Process

2.5 Trial Balance

2.6 Correction of Errors

ACTIVITY: PBL- Memo 1

ADJUSTING ENTRIES

3.1 Basics of Adjusting Entries

3.2 Types of Adjusting Entries

3.3 Journalizing and Posting Adjusting Entries

3.4 The Adjusted Trial Balance

\section{ACTIVITY: PBL-Memo 1 and 2}

\section{COMPLETING THE ACCOUNTING CYCLE}

4.1 Using a Work Sheet with

Excel application

4.2 Closing Entries

- Preparing Closing Entries

- Posting Closing Entries

- Preparing a Post-Closing Trial Balance

4.3 Preparation of Financial Statement

4.4 Reversing Entries

ACTIVITY: PBL-Memo 1 


\section{NO TOPIC/ACTIVITY}

5. ACCOUNTING FOR MERCHANDISING OPERATIONS

5.1 Merchandising Transactions

- Purchase and Sales

- Purchase Discounts

- Purchase Returns and Allowances

- Freight Costs

5.2 Recording the Transaction

- Periodic Inventory System

- Perpetual Inventory System

5.3 Adjusting Entries

5.4 Financial Statement for Merchandising Operations

5.5 Closing Entries

5.6 Post-Closing Trial Balance

ACTIVITY: PROBLEM SOLVING

6. ACCOUNTING FOR MANUFACTURING OPERATION

6.1 Environment for Manufacturing Operation

6.2 Manufacturing Cost Concept

6.3 Product Cost v. Period Cost

6.4 Financial Statements for Manufacturing Firms

ACTIVITY: PBL-Memo 1

PROBLEM SOLVING

7. SUBSIDIARY LEDGER AND SPECIAL JOURNAL

7.1 Internal Control

7.2 Subsidiary Ledgers

7.3 Special Journals

ACTIVITY: PBL-Memo 3

8. INCOMPLETE RECORDS

8.1 Single Entry System and Incomplete Records

8.2 Preparing the Income Statement

- Comparing Method \& Analysis Method

8.3 Preparing the Balance Sheet

- Comparing Method \& Analysis Method

ACTIVITY: PROBLEM SOLVING 


\section{NO TOPIC/ACTIVITY}

9. FINANCIAL STATEMENT ANALYSIS

9.1 Basics of Financial Statement Analysis

9.2 Horizontal Analysis with Excel application

9.3 Vertical Analysis with Excel application

9.4 Ratio Analysis:

9.5 Analysis using Excel

9.6 Interpretation of Results from the Analysis

ACTIVITY: PBL-Memo 4

10. CONCEPTUAL FRAMEWORK

10.1 Objectives of Financial Reporting

10.2 Qualitative Characteristics of Accounting Information

10.3 Elements of Financial Statement

10.4 Measurement and Recognition Principles

10.5 Assumptions

\section{ACTIVITY: LECTURE \& DISCUSSION}

After several brainstorming sessions among colleagues, we came - up with a set of driving questions, which were fundamental to the - project; this was done before we designed the project activities. Good driving questions would motivate students to seek more information. The driving questions embedded in the memos were designed to help students identify what they needed to learn in - order to solve the problems, and these were: 1. How can we, as accounts executives, record transactions and prepare financial statements so that accounting information gives a true and fair view of the business activities? 2. How can we, as investors, evaluate the financial performance of the business entity so that we can make sound business decisions?

The set of problems we had created and presented in the entry documents, which comprised four memos from the Finance Manager to the Assistant Accountant, are as shown in Table 3. For each memo given to the students, we attached other relevant documents, such as the background of the problems, and sources of documents (invoices, bills, receipts and vouchers) of the business transactions to assist the students in solving the problems. 
Table 2

Topics, Duration and Learning Outcomes of the Entry Documents

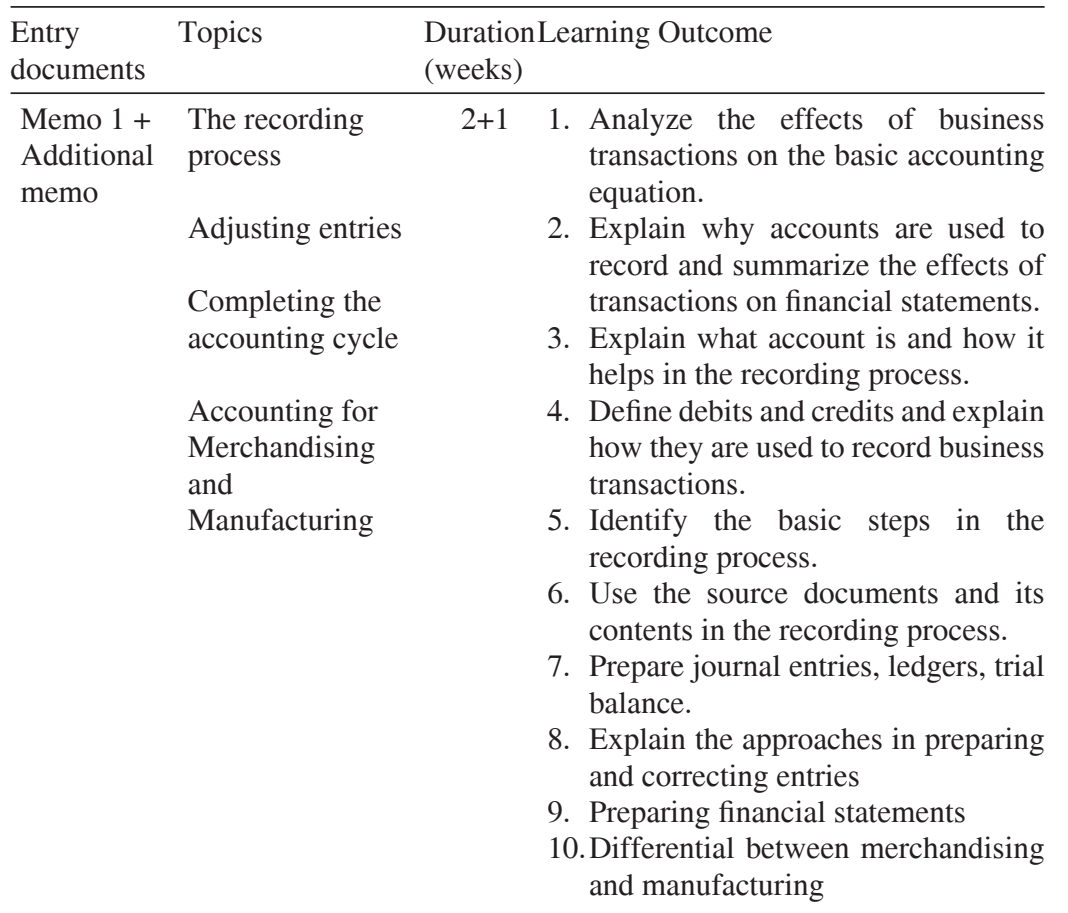

\section{Memo 2 Generally Accepted 1} Accounting

Principles

Adjusting entries
1. Explain how the matching concept relates to the accrual basis of accounting.

2. Explain why adjustments are necessary and list the characteristics of adjusting entries.

3. Journalize entries for accounts requiring adjustment.

4. Summarize the adjustment process and prepare an adjusted trial balance.

\begin{tabular}{|c|c|c|c|}
\hline Memo 3 & $\begin{array}{l}\text { Subsidiary ledger } \\
\text { and special journal } \\
\text { Accounting } \\
\text { Software } \\
\text { Presentation }\end{array}$ & 1.5 & $\begin{array}{l}\text { 1. Use Mr Accounting software. } \\
\text { 2. Use the subsidiary ledger. } \\
\text { 3. Demonstrate the use of special } \\
\text { journals in journalizing the } \\
\text { transactions. } \\
\text { 4. Test whether the subsidiary ledger } \\
\text { agrees with general ledger. } \\
\text { 5. Presentation skill }\end{array}$ \\
\hline
\end{tabular}




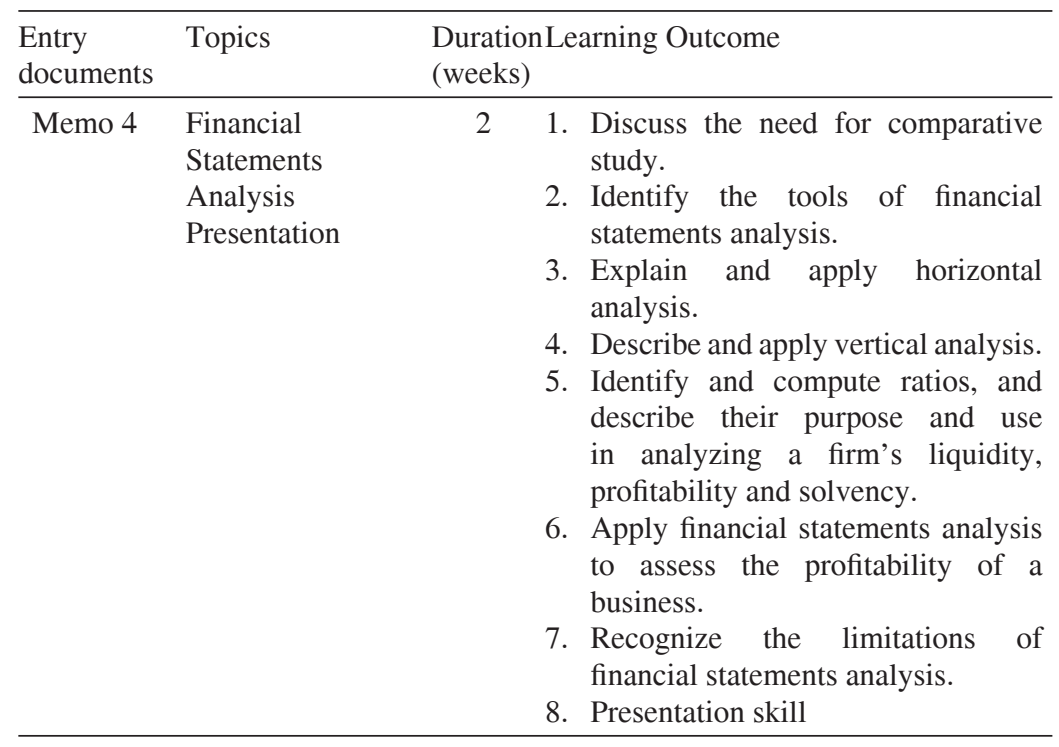

- Total Weeks $\quad 7.5$

Table 3

Entry Documents - Memos

\section{MEMO 1}

CTKAY FOOD SDN BHD

Memo

From: Dato' Kay (Finance Manager)

To: Ms CT, Assistant Accountant

Date: 23.7.2006

Subject: Bank Requirement for Loan Application

We received an offer to supply halal frozen food to Tesco outlets worldwide. In view of our business expansion, there is an urgent need for the firm to obtain fresh loans from financial institutions. One of the requirements for the loan application is the latest audited financial statements. In relation to this, please get the financial statements ready for auditing in two weeks' time. Please ensure that the financial statements for the year ended 30/6/06 are prepared according to the required format. 


\section{MEMO 2}

\section{CTKAY FOOD SDN BHD}

\section{CTKAY FOOD SDN BHD}

From: Dato' Kay (Finance Manager)

To: Ms CT, Assistant Accountant

Date: 6.8.2006

Subject: Miscellaneous Queries

I need your confirmation and advice on the following matters:

i) Our technician, Jufri Ismail, claimed that he had been underpaid amounting to a total of RM540 over the last few months. Please investigate and take corrective action, if necessary.

ii) Our MD's husband has asked me to buy a diamond necklace to be given to Puan Hajjah Wan Tempawan as a present on the occasion of their wedding anniversary. Attached is the invoice for your further action.

iii) Given that we are planning to appoint franchisees in the near future, please advise me on the appropriate method of recognizing "sales" of frozen cakes to the franchisees.

iv) Do we treat packaging materials as part of cost of goods manufactured or as operating expenses? Please justify our chosen method.

v) I noticed that our latest bill from Tenaga shows the last meter reading was done on 20 June 2006. Do we need to include usage of electricity from 21 June until 30 June 2006 in our income statement for the financial year ended 30 June 2006? Why or why not?

vi) I was informed by G-Mart Sdn Bhd that they received the same invoice 001376 dated 24 June 2006 twice from us. According to them the delivery that we made in June were as follows:

\begin{tabular}{ll}
\hline Date of Delivery & Total Invoice \\
\hline 4 June 2006 & RM4,500 \\
14 June 2006 & RM5,500 \\
24 June 2006 & RM5,500 \\
\hline
\end{tabular}

Did we double-bill G-Mart in June 2006?

Please consider the above matters and prepare your written response to all the points raised. I expect you to make the adjustments, if necessary, in the draft financial statements to be submitted on 13 August 2006. 


\section{MEMO 3}

\section{CTKAY FOOD SDN BHD}

\section{Memo}

From: Dato’ Kay (Finance Manager)

To: Ms CT, Assistant Accountant

Date: 3.9.2006

Subject: Mr Accounting

I was disappointed to discover that there were so many errors associated with the manual accounting system. MySoft Sdn Bhd, the developer of Mr Accounting has kindly let us use the software on a trial basis. Please re-enter all the transactions for last month using Mr Accounting. Please advise me whether we should shift to the computerized accounting system. Presentation should be arranged either on the 12th or 13th of September 2006.

MEMO 4

\section{CTKAY FOOD SDN BHD}

Memo

From: Dato’ Kay (Finance Manager)

To: Ms CT, Assistant Accountant

Date: 3.10.2006

Subject: Exit Strategy - A Potential Buyer

Due to strong demand from Tesco, there is an urgent need for company expansion. I received an offer from the management of Vision Food Sdn Bhd to buy all the shares in our company. Please consult me on this matter. The next meeting with Vision Food Sdn Bhd is on the 15.10.2006. Please ensure that all your working papers are ready to be presented to me on the 10.10.2006. Herewith, I attached the company's profile and financial information for your further action.

We gave the students an additional memo after Memo 1 to extend the date of submission after we found that the students were facing difficulties and were struggling to complete the task in memo 1 . The memo stated "With reference to my memo dated 23.7.2006, I have been informed by our external auditor that they want to postpone their audit job for another week. In light of this, you could submit the audited financial statement for the year ended 30.6.2006 by 13.8.2006." 
We documented our PBL project and named it "CTKAY PBL Documentation" which consisted of students' materials and an instructor's manual. Student materials included the aim and synopsis of the project; instructions to students; entry documents, student logs and assessment rubrics. To assist our lecturer facilitators in handling their PBL classes we provided further instructions as and when the need arose.

For their PBL project we assigned students to work in groups of five members. Each PBL and non-PBL session consisted of two hours with a group of 30 to 50 students per class. The PBL project contributed $30 \%$ of the total course marks. For the non-PBL group, we used their mid-term examination marks, as these were equivalent to the marks for a PBL project. The marks allocated for the PBL project were as follows: written report for each of the memos (4 (a 20\% each), two presentations for memos 3 and 4 (15\%) and student's logs and peer evaluation (5\%). We used assessment rubrics to evaluate the PBL project. Another $10 \%$ of the course marks comprised quizzes and assignments. For both PBL and nonPBL groups, the remaining marks for the course came from the final examination $(60 \%)$.

\section{MANAGING PBL IN CLASS}

As we had trained in the Buck Institute for Education (BIE) $)^{1}$, the way we handled the PBL in class was influenced by the approach introduced by the BIE. Learning using PBL for the first time was a challenge to the students since they were so used to the traditionallecture method. It was part and parcel of the PBL process in class to prepare the students' mindset and to keep them motivated. The process of motivating students in class, either to a group of students or to an individual student, was a continuous task for the lecturers. We have tried to expose the students to the current situations and challenges that they will face when they join the market place in the future. The exposure to the expectations on fresh graduates in the real world would help students become eager to learn accounting using PBL.

\footnotetext{
1 Information about the BIE can be found at http://www.bie.org/index.php/site/
} 
Teamwork is crucial as all problem-solving activities in PBL are done by the students in groups. We divided the students into small heterogeneous groups where we considered several aspects, i.e. ethnicity, gender, prior exposure in accounting and qualification at entry point. Managing and getting the cooperation of the group members was not an easy task. In the real world, these problems cannot be avoided, so the best thing to say is "Welcome to the real world!!!" The students were encouraged to settle their group conflicts by themselves.

Students were presented with a problem through the entry document created earlier. They were required to discuss and find out learning issues. They were also required to explore new information. At this point, the lecturers moved around to monitor the students' work and guided the students in their time management and work allocation. The students were allowed to exit from the problem by presenting their solution in either a written report or a group presentation. At the end of the session, we would conduct a debriefing to explain the process the students had undergone. This session was crucial to correct any misconceptions observed during the presentation/learning process and to highlight the importance of allowing the students to grapple with the issue or concepts in order to solve the ill-structured problems. Table 4 below shows an example of the process in conducting the activities in reference to memo 1. This process would reflect the stages provided in the facilitator's manual.

\section{Table 4}

Steps in Conducting the PBL-Sample Memo 1

First session

1. Distribute Instructions to Students.

2. Distribute Memo 1, Appendices 1 and 2 to students.

3. Discuss Instructions to Students with the whole class.

4. Assign students into groups.

5. Discuss the Memo 1 from Dato' Kay, Appendices 1 and 2 with the students.

6. Identify problem statement..* "How can we as ? do ? so that ?" (Refer to driving questions)

7. List of 'what we know' and 'what we need to know'.* 


\section{Possible solutions:}

What we know

- To prepare financial statements $(\mathrm{F} / \mathrm{S})$

- To be ready in two weeks' time

- For loan application

- F/S external users

- Manufacturing co.

- Frozen food industries

What we need to know

- Required format of financial statements (FRS Requirement)

- Recording process

8. Have the groups analyze a few documents/business transactions using accounting equations.

9. Revise with the whole class on how to analyze documents/ business transactions using accounting equations.

10. Have students make log entry.*

\section{Second session}

11. Have the groups discuss and prepare the following process:

- Journal entry / worksheet

- Posting T-Accounts

- Trial balance

12. Assign the students (homework) to differentiate the financial statement for different type (service, merchandizing and manufacturing companies) and form of business (sole proprietor, partnership and company).

\section{Third session}

13. Discuss the financial statement for different type of companies (service, merchandizing and manufacturing companies) and form of business (sole proprietor, partnership and company).

14. Have the groups prepare the financial statement for auditing.

\section{Fourth session}

15. Due project for Memo 1

16. Wrap-up and debriefing session

- Explain the process they have undergone.

- Check understanding and/or correct misconceptions observed during the learning process.

- Highlight the importance of allowing them to wrestle with the issues or theories/concepts to solve the problem.

* These steps may be repeated. 


\section{RESULTS}

\section{Overall Academic Performance in Financial Accounting Principles Course}

Based on the overall results of 1,148 students taking the Financial Accounting Principles course in the First Semester 2006/2007, we compared the academic performance of all students taught using the PBL method and students under the conventional method, as shown in Table 5. About $14 \%$ of PBL students scored A and A-, whereas for those students without PBL, only $6 \%$ of them scored an A or A-. Fifty one percent of the PBL students scored B+, B and B-, while the percentage of those without PBL was $47 \%$. For the lower grades $\mathrm{C}$ and $\mathrm{C}+$, less than $10 \%$ of PBL students were in that category, while those without PBL was at a higher rate of $18 \%$. The same applied for D and D+ grades where percentages of those students with PBL and without PBL were $8 \%$ and $18 \%$ respectively. As for the failure rate, about $3 \%$ of the PBL students failed the course while $9 \%$ without PBL failed the course.

\section{Table 5}

Result of All Students Taking Financial Accounting Principles

\begin{tabular}{|crrrr}
\hline GRADE & \multicolumn{2}{c}{ PBL $(\mathbf{n = 2 1 4})$} & \multicolumn{2}{c}{ NON PBL $(\mathbf{n = 9 3 4})$} \\
\hline A $(85-100 \%)$ & 11 & $5.14 \%$ & 10 & $1.07 \%$ \\
A- $(80-84.44 \%)$ & 18 & $8.41 \%$ & 46 & $4.93 \%$ \\
B+ $(70-79.44 \%)$ & 79 & $36.92 \%$ & 219 & $23.45 \%$ \\
B $(65-69.44 \%)$ & 37 & $17.29 \%$ & 119 & $12.74 \%$ \\
B- $(60-64.44 \%)$ & 23 & $10.75 \%$ & 115 & $12.31 \%$ \\
C+ $(55-59.44 \%)$ & 11 & $5.14 \%$ & 96 & $10.28 \%$ \\
C $(50-54.44 \%)$ & 10 & $4.67 \%$ & 76 & $8.14 \%$ \\
D+ $(45-49.44 \%)$ & 9 & $4.21 \%$ & 76 & $8.14 \%$ \\
D $(40-44.44 \%)$ & 8 & $3.74 \%$ & 92 & $9.85 \%$ \\
F $(0-39.44 \%)$ & 7 & $3.27 \%$ & 84 & $8.99 \%$ \\
X & 1 & $0.47 \%$ & 1 & $0.11 \%$ \\
\hline TOTAL & 214 & $100.00 \%$ & 934 & $100.00 \%$ \\
\hline
\end{tabular}

We ran the robustness test to ensure that the total results reflected the students' performance, and was not due to their coursework marks. The result showed that for both final exam and coursework, students from the PBL class scored higher marks than the non-PBL class. 


\section{Student Survey}

We conducted a survey of all the 267 students who had attended the PBL and the traditional non-PBL methods. This group of students represented $23 \%$ of the total number of students taking the Financial Accounting Principles course. The questionnaire used was adapted from Newman (2002). The survey asked students about how activities in the class had benefitted them. Opinion questions were on a 5-point Likert scale, 5 representing "strongly agree" and 1 for "strongly disagree".

\section{Quantitative Results}

Table 6 shows the sample's descriptive statistics. Based on the table, the composition of the PBL groups and non-PBL groups are comparable in terms of gender, degree program, prior education and prior accounting exposure.

Table 6

Descriptive Data-Background of the Respondents

\begin{tabular}{lccr}
\hline \multicolumn{4}{c}{ Frequency $(\%)$ of students $(\mathbf{N}=\mathbf{2 6 7}$, unless stated $)$} \\
\hline & PBL class & Non PBL class & Total \\
\hline No. of students & $166(0.62)$ & $101(0.38)$ & 267 \\
No. of classes & $7(0.7)$ & $3(0.3)$ & 10 \\
No. of lecturers & $5(0.71)$ & $2(0.29)$ & 7 \\
Gender: & & & \\
$\quad$ Female & $135(0.81)$ & $82(0.81)$ & 217 \\
$\quad$ Male & $31(0.19)$ & $19(0.19)$ & 50 \\
Degree Program $(\mathrm{N}=265):$ & & & \\
$\quad$ Accounting & $119(0.72)$ & $71(0.70)$ & 190 \\
$\quad$ Non-Accounting & $46(0.28)$ & $29(0.30)$ & 75 \\
Prior Education ${ }^{1}(\mathrm{~N}=264):$ & & & \\
$\quad$ STPM & $48(0.29)$ & $32(0.32)$ & 80 \\
$\quad$ Matriculation & $116(0.71)$ & $68(0.68)$ & 184 \\
Prior Accounting Exposure $(\mathrm{N}=261):$ & & & \\
$\quad$ Yes & $139(0.84)$ & $88(0.87)$ & 227 \\
$\quad$ No & $24(0.16)$ & $10(0.13)$ & 34 \\
\hline
\end{tabular}

2 STPM and Matriculation (equivalent to A-Levels qualification) are two preUniversity programs that are offered to students after their SPM (equivalent to O-Levels qualification). The qualifications are recognized for entrance to public universities. 
Table 7 compares the performance of the PBL students versus nonPBL students in terms of whether they were grade A achievers or non-A graders. Consistent with Table 5, Panel A in Table 7 shows that PBL students moderately out-performed non-PBL students as indicated by the Pearson chi-square $(\mathrm{p}=0.07)$. Panel $\mathrm{B}$ expands the result in Panel A by splitting non-A graders into grades B, C, D and F. Similarly, consistent with Table 5, the proportion of students with A or B grades was higher for PBL classes (84\%) than non-PBL classes $(79 \%)$.

Table 7

Results of Students Surveyed

Panel A: Grade A and Non-A

Frequency $(\%)$ of students $(\mathrm{N}=264)$

\begin{tabular}{lccc}
\cline { 2 - 4 } & PBL class & Non PBL class & Total \\
\hline Grade A & $26(0.16)$ & $8(0.08)$ & 34 \\
Grade Non-A & $138(0.84)$ & $92(0.92)$ & 230 \\
\hline Total & 164 & 100 & \\
\hline
\end{tabular}

Chi-square test $\left(\mathrm{X}^{2}\right)=3.42$ at $\mathrm{p}$ value $=0.065$

Panel B: Individual mean result and grades

\begin{tabular}{|ccccc}
\hline Grades & $\begin{array}{c}\text { Mean } \\
\text { Overall Marks }\end{array}$ & \multicolumn{3}{c}{ Frequency (\%) of students } \\
\cline { 3 - 5 } & PBL (non-PBL) & PBL class & $\begin{array}{c}\text { Non PBL } \\
\text { class }\end{array}$ & Total \\
\hline A & $83.12(81.75)$ & $26(0.16)$ & $8(0.08)$ & $34(0.13)$ \\
B & $69.42(70.07)$ & $113(0.68)$ & $72(0.71)$ & $185(0.69)$ \\
C & $54.42(53.40)$ & $12(0.07)$ & $10(0.10)$ & $22(0.08)$ \\
D & $44.09(43.67)$ & $11(0.07)$ & $6(0.06)$ & $17(0.06)$ \\
F & $37.00(31.00)$ & $2(0.01)$ & $4(0.04)$ & $6(0.02)$ \\
\hline Total & & 164 & 100 & 264 \\
\hline
\end{tabular}

Table 8 shows the average marks obtained by the PBL class versus the non-PBL class, in the context of accounting or non-accounting degree programs. Students in accounting programs scored higher than non-accounting programs. For both accounting and non-accounting 
programs, the scores obtained by students were higher for the PBL classes than the non-PBL classes. However, for the non-PBL classes, the average scores in the non-PBL classes for accounting programs was moderately significant $(\mathrm{p}=0.092)$ compared to the non-accounting non-PBL classes.

\section{Table 8}

Comparison Results Between PBL and Non-PBL classes for both Non-Accounting and Accounting Program (Using T-test)

\begin{tabular}{llllll} 
Program & Overall Marks & N & Mean & t-value & $\begin{array}{c}\text { Sig } \\
\text { (2-tailed) }\end{array}$ \\
\hline Accounting Program & PBL class & 118 & 72.08 & 1.655 & .100 \\
& Non-PBL class & 71 & 69.92 & 1.693 & $.092^{*}$ \\
\multirow{2}{*}{ Non-Accounting Program } & PBL class & 45 & 59.38 & 1.655 & .386 \\
& Non-PBL class & 28 & 56.61 & 0.906 & .368 \\
\hline
\end{tabular}

Table 9 shows the student perceptions of how they had benefitted from activities in class. From the table, we can see that the PBL class provides significant benefits in the following aspects: presentation skills, ability to work as a member of the team, leadership ability and ability to use IT. Contrary to expectation, PBL groups scored lower in terms of stimulating students to carry-on learning although it was not statistically significant. We are of the view that this could be due to the students' perception that they felt over-burdened as compared to the non-PBL groups.

\section{Qualitative Results}

The survey instrument also provided an avenue for students to comment in detail about their learning experience. Based on what students had said about their PBL learning experience we were able to obtain some insights into how we should handle PBL classes in the future. We categorized these student feedback into four themes: PBL is an acceptable way of learning accounting; PBL is a challenging way of learning, but it offers great benefits; PBL helps student to improve team work, communication and other soft skills; and PBL is only suitable for students with some basic accounting knowledge. 


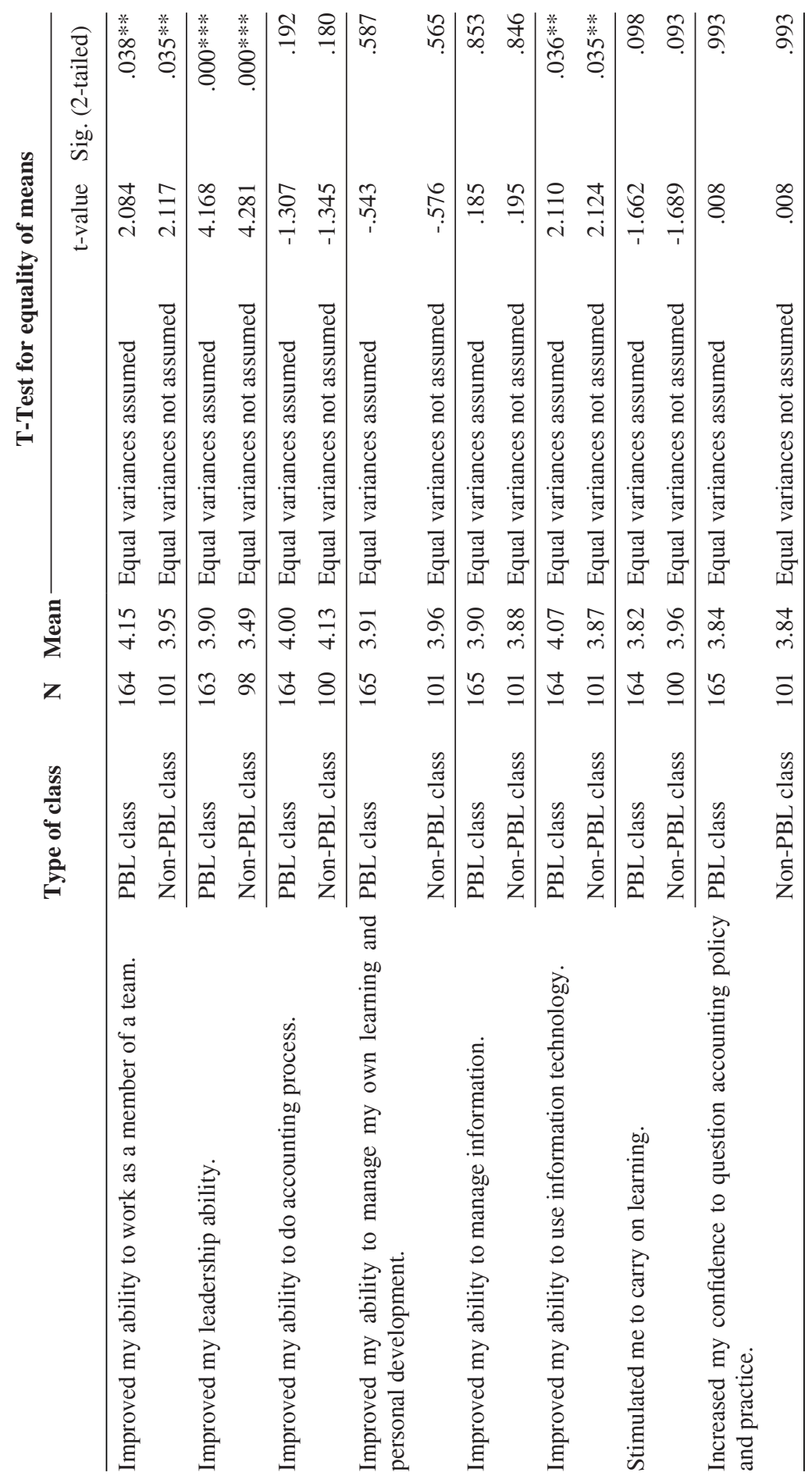




\section{PBL is an Acceptable Way of Learning Accounting}

Examples of student feedback:

I agree with learning Financial Accounting Principles in this semester. It is because I can learn this subject in various ways not only depend on textbooks.

PBL is a two-way communication and learning method. We may encounter problems when we are doing PBL. However, that's the learning process that we should go through. We should learn to solve problems but not to keep away from them. PBL is a good try for me. Hope to learn more with PBL learning method.

I got more benefits from PBL. PBL teaches me to be more independent. Before this, I'm very afraid to take accounting course because I have no basic. But with PBL, I gain new knowledge and perceptions. I enjoy to be with lecturer and members.

Very enjoyable, fun and challenging. A new approach in learning. Should be continued in future.

PBL is something new to me. When I first get it, I feel confuse and don't even know how to start it. Luckily, my lecturer makes a very good arrangement and I get in a very nice PBL group with helpful members. Although there was argument and improve in our communication skill. I get to learn many things that I can't gain from text books. At beginning, I was afraid. I lost myself in PBL, but my lecturer discusses the book's exercise with us too. This is what I appreciate the most. Thanks a lot.... you are a good lecturer.

\section{PBL is Challenging Way of Learning but Offer a Great Benefit}

Examples of student feedback:

I am still blurred but I enjoy much.

It is a burden for the students taking the program. We were nothing when we entered the class; still it is seem the same after the whole semester class. Perhaps, we had a stronger ability to face with challenge if compared to the non-PBL project student. Yet, I still appreciate the working that makes me tough. 
I think the PBL is very challenging. I also feel tension about it. However, I gain more knowledge in the PBL.

Very practical, but is very hard to do it if group members don't want to communicate. Overall PBL is a good learning process.

For me it is challenging. From PBL, I feel like I have already involved in the real accounting world. It teaches me how to react to certain situations. I gained a lot of knowledge that cannot get through textbooks. I love PBL. Thanks.

At first I was so boring with PBL because lot of works to do. But I know PBL can improve my knowledge about financial accounting. I learnt more about account from PBL. I also have confident with my English to communicate. Thank you to my lovely lecturer.

Well I think PBL does help me in a lot of ways such as learning new things that we cannot learn from books. It is also burden me but luckily I can still manage it well. I hope in another PBL, I can do better.

\section{PBL Helps Student to Improve Team Work, Communication and Other Soft Skills}

\section{Examples of student feedback:}

I feel so tired to do PBL. I always become stress and angry when I do this work. I think, for this semester when I spent more time with PBL, my work in PBL is complete and become a good work. Although I was so tired with PBL, it is good for me. PBL gives me experience how to solve problem with group members and communicate well with them. Besides that, PBL gives me knowledge how to work in company. At last, I enjoyed with PBL.

Working in a group is pretty challenging for me. Different people have different attitude. Tolerance is seriously needed. Some members just maintain their stationary position, while some overload themselves. Ineffective communication and lack of trust are the issues here. Just glad everything ended in a good way. Thanks so much to my lecturer for her guidance. I really learned a lot.

Team members can help students without basic to understand the topics, especially to complete assignment. 


\section{PBL is only Suitable for Students with Some Basic Accounting}

Examples of student feedback:

This way of learning is not suitable for the students who don't have any basic. They easily give up and hard for us to do any assignment. Most of them, just use "I don't have basic, I don't know how to do. You do it" as a reason.

I think that doing PBL is not the best way for us without basic of accounting to learn. Although it's good, but that's still got some part make me confuse. Also, it's really a waste of time. I didn't have enough time to read my book.

As a student who doesn't have any basic in accounting, it is so difficult for me to understand.

-

\section{CONCLUSION}

PBL is an innovative teaching method because it uses problems in stimulating students to learn. It is timely for us to use PBL in our teaching; this is to answer the call of the Malaysian Institute of Accountants (MIA), professional bodies and employers in the market to better prepare our students to face the real world. They must not only be equipped with technical expertise, but also the softskills that will give them the competitive edge. The major challenge for educators is how to carefully develop the problems in order to achieve the learning outcomes of the course. Another issue of concern is student attitude towards the use of PBL in the classroom. This is because student acceptance of PBL is still low since most of them are still used to the conventional way of learning.

In UUM, PBL was a new approach when we introduced it to the Financial Accounting Principles course in the First Semester, 2006/2007 session. Although a new method, PBL seems promising as an effective pedagogical approach. We came to this conclusion on the basis of our analysis of the results of the students at the end of the semester as well as their feedback about the benefits of the activities in class. In general, the results showed that students in the PBL class out-performed the students in a non-PBL class. From the survey on the perceptions of the students, we found that the students 
had agreed that PBL enhances their presentation, teamwork, leadership and IT skills. Based on the student comments in the openended question, we found consistent agreement that PBL helps them to improve their soft skills. Most of the students however, felt that although PBL offered many benefits, it was a challenging way of learning. This new method demanded more effort, contributions and participation from them.

Moving forward, we find it instructive to track the progress of the students who had participated in PBL as they advanced into their degree program. Perhaps it would be feasible to conduct semi-structured in-depth interviews on certain areas of interest to help us further assess the sustainability and impact of PBL on the student learning process. These areas include aspects of selfdirected behavior, group learning ability and problem solving skills. Feedback from students could also help us in designing feasible PBL problems to assist their learning process.

\section{ACKNOWLEDGEMENT}

The authors would like to acknowledge the helpful suggestions made by an anonymons reviewer of this article. An earlier version of the paper was presented at the International Conference on Teaching \& Learning in Higher Education, November 2009. Kuala Lumpur. The authors would also like to thank Masanita Mat Noh, Azharudin Ali and Dr Mohamad Hisham Selamat for their early involments in developing the PBL module used in this article.

\section{REFERENCES}

Accounting Education Change Commission (1990). Objectives of education for accountants: Position statement number one. Issues in Accounting Education, 5(2), 307-312.

Azer, S.A. (2009). What makes a great lecture? Use of lectures in a hybrid PBL curriculum. Kaohsiung J Med Sci, 25(3), 109115.

Breton, G. (1999). Some empirical evidence on the superiority of the problem-based learning (PBL) method. Accounting Education, 8(1), 1-12.

Clouston, T.J. \& Whitcombe, S. W. (2005). An emerging person centred model for problem-based learning. Journal of Further and Higher Education, 29(3), 265-275. 
Duch, B. J., Groh, S. E. \& Allen, D.E. (2001). The power of problembased learning. Sterling, VA.

Farnsworth, C. (1994). Using computer simulations in problembased learning. In Hung, Educational Research Review, 4, 118-141.

Flanagan, J. (1997). Applying problem-based learning to the first year accounting curriculum. Final report for a 1997 national teaching development grant. School of Business \& Informatics, North Sydney.

Hala Tuju 2 (2006). Reassessment report on accounting programs at public universities of Malaysia. Ministry of Higher Education, Malaysia.

Hansen, J. (2006). Using problem-based learning in accounting. Journal of Education for Business March/April, 221-223.

Hung,W. (2006). The 3C3R model: A conceptual framework for designing problems in PBL. Interdisciplinary Journal of Problem-based Learning, 1(1), 55-77.

Hung,W. (2009). The 9-step problem design process for problembased learning: Application of the 3C3R model. Educational Research Review, 4, 118-141.

Kirschner, P. A., Sweller, J., \& Clark, R. E. (2006). Why minimal guidance during instruction does not work: An analysis of the failure of constructivist, discovery, problem-based, experiential, and inquiry-based teaching. Educational Psychologist, 41(2), 75-86.

Lai, P., Tang, C., Arthur, D., \& Leung, S.F. (1999). Who benefits from portfolio assessment in problem-based learning nursing courses? In J. Conway \& A. Williams (Eds.), Research and development in problem-based learning: Themes and Variations in PBL, 1, Newcastle: Australian Problem-Based Learning Network. (pp. 150-159). Retrieved from http:// teaching.polyu.edu.hk/datafiles/R76.pdf.

Newble, D. J., \& Clarke, R. M. (1986). The approaches to learning of students in a traditional and in an innovative problem-based medical school. Medical Education, 20, 267-273.

Newman M (2002) Methodology working paper 9: Development and testing of instrumentation for a follow-up impact study of an educational intervention. Retrieved from http://hebes. mdx.ac.uk/teaching/Research/PEPBL/methpap9.pdf.

O'Neill, P. A. (2000). The role of basic sciences in a problem-based learning clinical curriculum. Medical Education, 34, 608-613. 
Siaw, I.S.C. (2000). PBL experience in business programs: Do disciplines matter? The 2nd Asia Pacific Conference on PBL, Temasek Polytechnic, Singapore.

Van Gessel, E., Nendaz, M. R., Vermeulen, B., Junod, A., \& Vu, N. V. (2003). Basic science development of clinical reasoning from the basic sciences to the clerkships: A longitudinal assessment of medical students' needs and self-perception after a transitional learning unit. Medical Education, 37, 966974.

Verhoeven, B. H., Verwijnen, G. M., Scherpbier, A. J. J. A., Holdrinet, R. S. G., Oeseburg, B., and Bulte, J. A., (1998). An analysis of progress test results of PBL and non-PBL students. Medical Teacher, 20(4), 310-316.

Vernon, D. T. A., \& Brake, R. L. (1993). Does problem-based learning work? A meta analysis of evaluative research. Academic Medicine, 68, 550-563. 


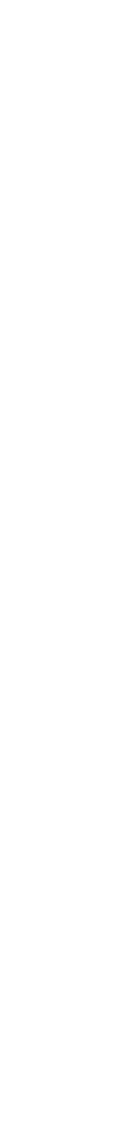

